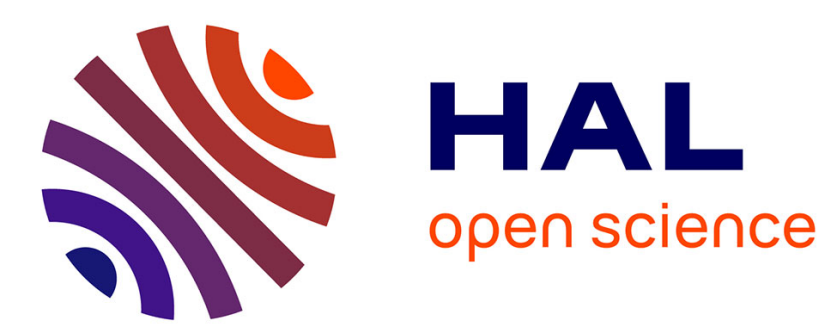

\title{
Time of birth and daily activity mediated by feeding rhythms in the pregnant rat
}

M. J. Bosc, Agnès Nicolle, Dorothée Ducelliez

\section{To cite this version:}

M. J. Bosc, Agnès Nicolle, Dorothée Ducelliez. Time of birth and daily activity mediated by feeding rhythms in the pregnant rat. Reproduction Nutrition Développement, 1986, 26 (3), pp.777-789. hal00898492

\section{HAL Id: hal-00898492 \\ https://hal.science/hal-00898492}

Submitted on 1 Jan 1986

HAL is a multi-disciplinary open access archive for the deposit and dissemination of scientific research documents, whether they are published or not. The documents may come from teaching and research institutions in France or abroad, or from public or private research centers.
L'archive ouverte pluridisciplinaire $\mathbf{H A L}$, est destinée au dépôt et à la diffusion de documents scientifiques de niveau recherche, publiés ou non, émanant des établissements d'enseignement et de recherche français ou étrangers, des laboratoires publics ou privés. 
Reprod. Nutr. Dévelop., 1986, 26 (3), 777-789.

\title{
Time of birth and daily activity mediated by feeding rhythms in the pregnant rat
}

\author{
M. J. BOSC, Agnès NICOLLE, Dorothée DUCELLIEZ
}

Station de Physiologie de la Reproduction, I.N.R.A., Nouzilly, 37380 Monnaie, France.

\begin{abstract}
Summary. The temporal relationship between time of birth and daily physical activity has been studied in rats submitted to different feeding rhythms. Animals, put under $14 \mathrm{~h}$ of light and $10 \mathrm{~h}$ of darkness (lights on from 6 to $20 \mathrm{~h}$ ), were isolated at mating (day 1 of gestation) and assigned from day 8 to one of five groups. Group $\mathrm{C}$ was fed ad libitum, and groups 2PF, 9PF, 14PF and 21PF had food available for three hours per day from 2, 9, 14 and $21 \mathrm{~h}$, respectively. In groups $9 \mathrm{PF}$ and $14 \mathrm{PF}$, births were clustered in one single period during the night between days 22 and 23 of gestation. In groups C, 2PF and 21PF, births were distributed into two periods, during the afternoon of day 22 before darkness and after dawn of day 23 . The birth rates of these groups were $55.3,74.2$ and $27.6 \%$, respectively, on day 22 and $44.7,25.8$ and $72.4 \%$ on day 23 . No births occurred during the times that food was available; they were noted in all groups at times when the animals were least active according to records kept throughout gestation. Thus, restricting food availability to periods of normal inactivity (groups $9 \mathrm{PF}$ and 14PF vs group C) led to a major shift in the time of delivery as well as to a distortion of the normal activity patterns. These results confirm that feeding rhythms are potent entrainers of birth time in rats and that they interact with the light regime. Pregnant rats seem to be organized so that birth either precedes the main daily physical activity or follows it, depending upon the environmental conditions.
\end{abstract}

\section{Introduction.}

The time of birth is photodependent in rats. When caged alone and fed at will they show two main periods of delivery; the relative number of births during these periods and the respective times they occur on each of the last two days of gestation characterize the photodependent effect (Lincoln and Porter, 1976 ; Bosc, 1981). Between these periods, few or no parturitions occur ; this interval coincides with the dark phase of the photoperiod (Bosc, 1981).

Other environmental cues, such as an imposed feeding rhythm, may affect birth distribution in this nocturnal species (Bosc and Nicolle, 1985). When food and water are given only during the early light phase of a standard light regime, most deliveries occur during the night between the usual last two days of pregnancy. This periodic presentation of food and water at a given daily time also entrains a feeding rhythm (Obled et al., 1977 ; Morimoto et al., 1979 ; Miyabo et 
al., 1980) which differs from that of animals fed ad libitum, since the latter usually eat during the nocturnal period (Besch, 1970 ; Obled et al., 1975, 1977).

The difference in birth time between rats fed at will and those with an imposed feeding rhythm has suggested the existence of an obligatory shift between two types of activity : labor on one hand, and feeding or related activities on the other (Bosc and Nicolle, 1985). The aim of the present study was to test this assumption. Time of birth and daily activity were recorded in rats submitted to a standard photoperiod and fed, according to the experimental group, during the resting or active period of the light-dark cycle.

\section{Material and methods.}

Rats from strain 03 of our colony (Wistar origin) were used. They were kept in constant temperature rooms $\left(20^{\circ} \mathrm{C} \pm 1\right)$ under a standard light regime of $14 \mathrm{~h}$ of light and $10 \mathrm{~h}$ of darkness (14L/10D) with lights on from 6 to $20 \mathrm{~h}$. At 70 90 days of age, the females were caged with a male and mating was assessed by the presence of spermatozoa in vaginal smears (day 1 of pregnancy). Mated females were then isolated (one/box) and allocated to one of five experimental groups. One pregnancy was allowed per female. During the experimental period they received a commercial food (U.A.R. Paris), and water, available at will, was renewed twice a week; the litter in the boxes was not changed at any time during pregnancy.

Food was given ad libitum to the control group (C); in the other four groups it was available for only three hours per day from day 8 of gestation. Depending on the group, food was available at the following times: 2 to $5 \mathrm{~h}$ (group 2PF), $9 \mathrm{~h}$ to noon (group 9PF), 14 to $17 \mathrm{~h}$ (group 14PF) and $21 \mathrm{~h}$ to midnight (group 21PF). In order to facilitate food distribution during darkness (groups 21PF and $2 \mathrm{PF}$, half of the rats were put under an inversed standard photoperiod with lights on from $17 \mathrm{~h} 45$ to $7 \mathrm{~h} 45$. The transition from the normal to the inversed photoperiod was achieved progressively over four days, 5-6 weeks before the males were introduced. About one-half of the animals of the control group were submitted to this inverted light regime; as their birth distribution was similar to that under the original light regime, the data of the two subgroups were pooled for analysis. Analysis was carried out after the data had been reconverted into the actual times of the colony.

Observations were done as previously described (Bosc and Nicolle, 1980). The rats were checked every two hours on days 22 and 23 of gestation, and their births were therefore plotted at two-hour intervals, the onset of expulsion being the time of delivery. Birth distributions were then compared using the Kolmogoroff-Smirnof test (Siegel, 1956) or as to the interval between birth and a given reference point such as last dawn or last feeding; the latter was chosen according to observed birth distribution (variance analysis; Vessereau, 1960). The homogeneity of the five groups was assessed on the basis of litter size, still-birth rate and birth weight of live pups (Vessereau, 1960). The weight gain of the dams between days 8 and 20 of gestation and fertility was also taken into account in each group. 
In the present experiment, the individual activity of additional rats was monitored throughout gestation (two recording sessions per group; each group treated as previously described). The oscillations produced by each animal were recorded on a polygraph $(6.9 \mathrm{~mm} / \mathrm{min})$ (Rapidgraph RP2, Enertec Schlumberger, France) by a transducer (capteur SIAC-VHAT 64BL, Paris) in each box, fixed on a floating floor and forming a whole with the cover. The activity corresponding to total motor activity was monitored $15 \mathrm{~min} / 30 \mathrm{~min}$. The two $15-\mathrm{min}$ periods were considered as representative of hourly activity and were analysed in two ways. First, the main periods of activity were visualized individually for a whole gestation. The hours during which the rats were active for at least $25 \%$ of the time were determined and represented by a dark horizontal bar for each 24-hour period, each day also being represented by a line underneath the bar. Second, the total activity time per hour and per rat was taken into account at three 24hour periods, at definite stages of pregnancy, i.e. from noon on days 6,14 and 20 of pregnancy. To test homogeneity per group and per stage of gestation, the Spearman rank coefficient (Siegel, 1956) was used. The total hourly activity time of a group was also used to study homogeneity at the three stages of gestation or to compare the five groups at one stage.

\section{Results.}

The rats fed at will (group $\mathrm{C}$ or control group) had a biphasic birth distribution : $55.3 \%$ of the deliveries occurred on the afternoon of day 22 of gestation and $44.7 \%$ on the morning of day 23 (figs. $1 \mathrm{a}, 1 \mathrm{~b}$ ). The rats fed at the beginning or end of the dark part of the light/dark cycle (groups 21PF and 2PF, respectively) also showed two birth periods which started at the same times as observed in group $\mathrm{C}$, but the relative number of rats delivering during each of these periods depended on the feeding rhythm $(P<0.01)$. Thus, $74.2 \%$ of the births occurred on day 22 in group $2 \mathrm{PF}$, whereas $72.4 \%$ of them were observed on day 23 in group 21PF (fig. 1a). Groups 21PF and 2PF differed from group $C$ in this respect ( $\mathrm{P}<0.05$ or $<0.01$ ). In these three groups ( $\mathrm{C}, 21 \mathrm{PF}$ and $2 \mathrm{PF}$ ), the absence of deliveries between the two birth periods corresponded to night, and this phenomenon was more marked in groups 21PF and 2PF than in group $C$ (fig. 1a). The rats fed during the first or second part of the light phase (groups 9PF and 14PF, respectively) had a single birth period located during the last night of gestation. Their birth distributions were similar $(P>0.05)$ but differed from the other three groups (C, 2PF and 21PF ; $P<0.01$ or $<0.001$ ).

As delivery occurred at definite periods, it was possible to estimate the interval between onset of expulsion and a given reference point (table 1). When dawn (or lights on) was taken as the reference point for the births on day 22 of gestation, this interval differed in rats fed during the light phase (groups 9PF and 14PF) from that of rats fed during the dark phase (groups 2PF and 21PF) ( $18 \mathrm{~h} 30$ and

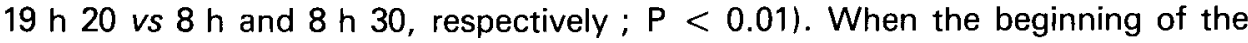
last feeding was taken as the reference point, the interval between feeding and parturition on day 22 or 23 was different in rats fed during the light phase (group 
9PF vs group 14PF ; $15 \mathrm{~h} 30$ vs $11 \mathrm{~h} 20 ; \mathrm{P}<0.01$ ) and in those fed during the night (group $2 \mathrm{PF}$ vs $21 \mathrm{PF} ; \mathrm{P}<0.01 ; 12 \mathrm{~h} 30$ vs $17 \mathrm{~h}$ on day $22,9 \mathrm{~h}$ vs $12 \mathrm{~h}$ on day 23).

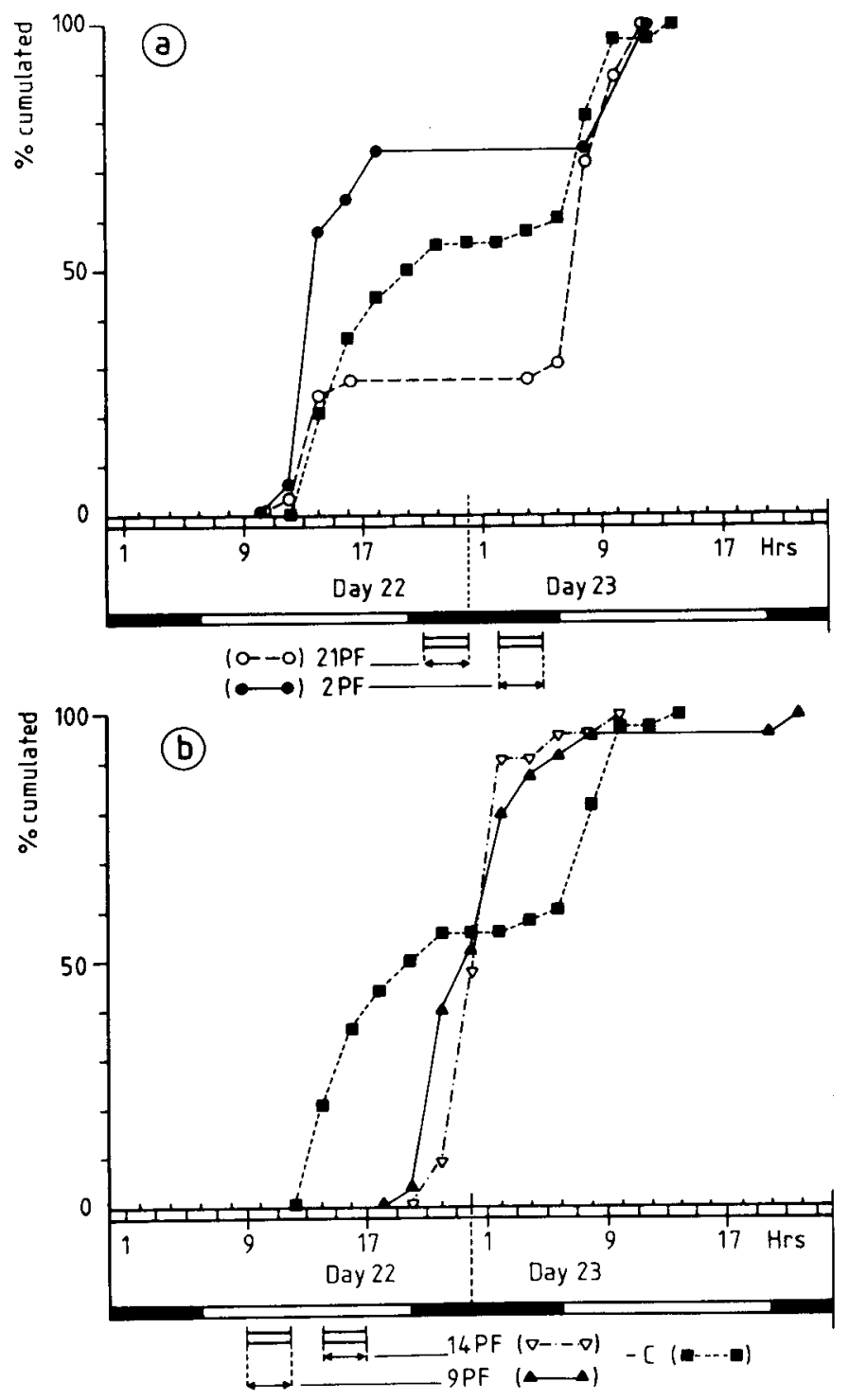

FIG. 1. - Birth distribution on days 22 and 23 of gestation in rats under the standard photoperiod and fed " ad libitum " (group C) or fed 3 hrs daily from day 8 of gestation (other groups) : Part a : group $\mathrm{C}(\mathrm{n}=38)$ and groups $2 \mathrm{PF}(\mathrm{n}=31)$ and $21 \mathrm{PF}(\mathrm{n}=29)$ which had food available from 2 or $21 \mathrm{hr}$ respectively. Part $b$ : group $C$ (repetition) and groups $9 P F(n=25)$ and $14 P F(n=23)$ which had food available from 9 or $14 \mathrm{hr}$ respectively. The LD cycle and the respective times of food avaibility are indicated at the bottom of each panel. 
TABLE 1

Interval (h, $\mathrm{min}$ ) between onset of expulsion and dawn (I) or beginning of last feeding (II) preceding birth at days 22 and 23 of gestation.

\begin{tabular}{|c|c|c|c|c|c|c|c|c|}
\hline \multirow{2}{*}{ Group } & \multicolumn{4}{|c|}{ Day 22} & \multicolumn{4}{|c|}{ Day 23} \\
\hline & $(n)$ & 1 & II & (sd) & $(n)$ & 1 & II & (sd) \\
\hline C & (21) & 10.45 & - & $(2.40)$ & (17) & 2.40 & - & $(2.05)$ \\
\hline 2PF & (23) & 8.30 & 12.30 & $(1.40)$ & (8) & 5.00 & 9.00 & $(1.00)$ \\
\hline 9PF & (24) & 18.30 & 15.30 & $(3.00)$ & - & & & \\
\hline $14 \mathrm{PF}$ & (23) & 19.20 & 11.20 & $(2.30)$ & - & & & \\
\hline $21 \mathrm{PF}$ & (8) & 8.00 & 17.00 & $(1.00)$ & (21) & 3.00 & 12.00 & $(1.30)$ \\
\hline
\end{tabular}

Group $C$ : rats fed at will; groups $2 \mathrm{PF}, 9 \mathrm{PF}, 14 \mathrm{PF}$ and $21 \mathrm{PF}$ : from day 8 of gestation, food was available for three hours daily from $2,9,14$ and $21 \mathrm{~h}$, respectively.

Litter size and birth weight varied together with the length of gestation. It was difficult to take into account these three parameters for a statistical analysis according to birth time. Nevertheless, the five groups were homogeneous for litter size, number of dams with still-born and still-birth rate $(P>0.05)$ (table 2). Fertility was the same in the five groups $(P>0.05)$, but in group 14PF it was less than in the other four groups (table 2). The relative weight gain of dams between days 8 and 20 of gestation varied according to the group $(P<0.01)$; it was higher in group $C$ than in tive other four groups $(P<0.01)$ and less in group 14PF than in groups $2 \mathrm{PF}, 9 \mathrm{PF}$ and $21 \mathrm{PF}(\mathrm{P}<0.01$ ) (table 2 ). In fact, $52.2 \%$ of the rats in group 14PF presented a weight loss, whereas only a limited number of dams in the other groups lost weight : $0 \%$ in group $C, 3.2,16.0$ and $17.9 \%$ in groups $2 \mathrm{PF}, 9 \mathrm{PF}$ and $21 \mathrm{PF}$, respectively. Therefore, it appears that the regime in which food was offered during the second half of the light phase was the most disturbing.

TABLE 2

Characteristics of the five experimental groups.

\begin{tabular}{lccccc}
\hline Group & $\mathrm{C}$ & 2PF & $9 \mathrm{PF}$ & $14 \mathrm{PF}$ & 21PF \\
\hline Dams (n) & 38 & 31 & 25 & 23 & 29 \\
Litter-size (m) & 10.1 & 10.0 & 9.1 & 9.9 & 10.8 \\
\% of dams with & 15.8 & 25.8 & 20.0 & 26.1 & 17.2 \\
still-born pups & 1.8 & 5.1 & 2.6 & 2.6 & 4.1 \\
\% of still births & 6.0 & 5.3 & 5.6 & 5.4 & 5.2 \\
Birth Weigtht (gr) of & 67.9 & 75.6 & 65.8 & 57.5 & 70.7 \\
live pups & 0.266 & 0.105 & 0.080 & 0.005 & 0.070 \\
Fertility (\%) & & & \\
Relative weight gain (*) & &
\end{tabular}

(*) Relative weight gain of dams between days 8 and 20 of gestation $=$ Wt.d.20 - WT.d.8 
The general motor activity of the five groups was monitored throughout gestation. Figures 2 and 3 show the main periods of activity from day $4(13 \mathrm{~h})$ to the end of gestation in 6 different rats. The control animals (figs. 2a, 3a), fed at will, were mostly active during darkness, whatever the day of gestation. Those fed at the beginning or end of the dark phase (groups 21PF, fig. $2 \mathrm{~b}$ and group 2PF, fig. 2c) remained active during darkness, but from the beginning of periodic food presentation (day 8 of gestation) and as gestation progressed, their main activity

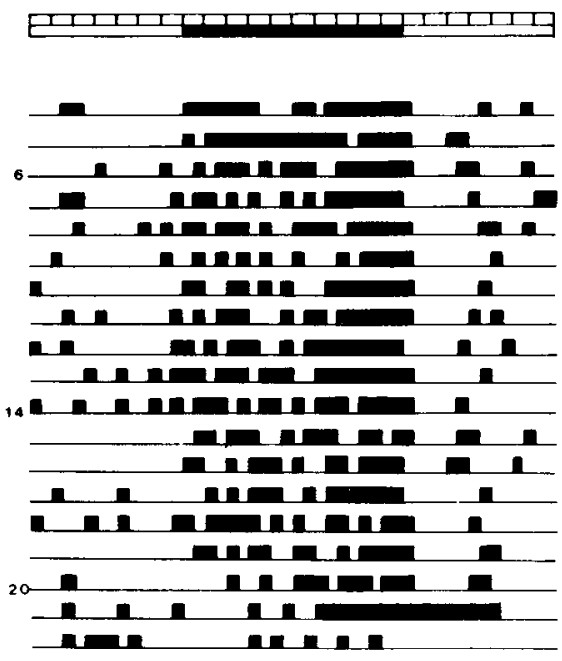

FIG. 2. - Main daily period of activity during gestation in 3 rats according to food availability. Part a : (top left) group C, fed at will : Part $b$ : (top right) group 21PF, fed from 21 h ; Part c : (bottom right) group 2PF, fed from $2 \mathrm{~h}$. The circadian scale and the light/dark cycle are given at the top of each panel. Each line represents a 24-hour period starting on day 4 at $13 \mathrm{~h}$. Horizontal dark bars indicate an activity time of $>25 \%$ of the corresponding hour. Vertical lines indicate the respective periods during which food was available, depending on the treatment.
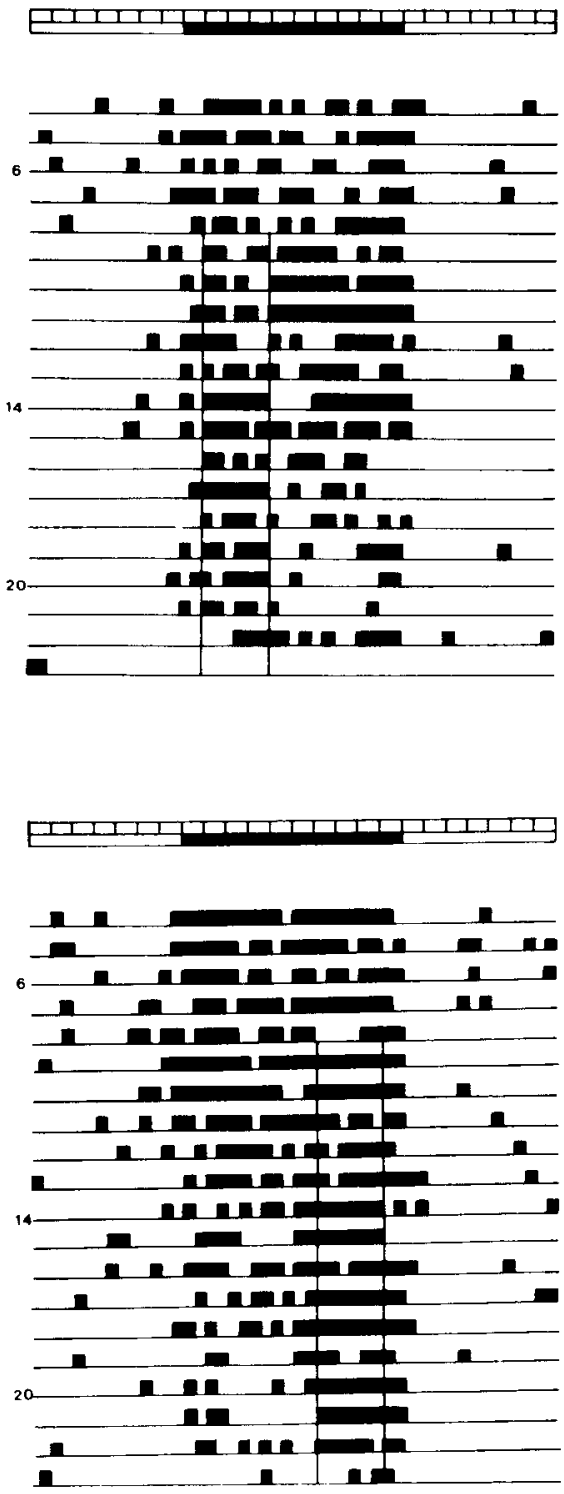
periods were concentrated around and during the respective times that food was available. When food was given at the beginning or end of the light phase (group 9PF, fig. 3c and group 14PF, fig. 3b), the rats were also active during its presentation (from day 8); daily spurts of activity were evident from about midgestation but, in general, the rats became progressively less active during the night. All monitored rats gave birth at the times noted for their respective groups (figs. 1a, 1b), times which occurred before or after the respective main, daily
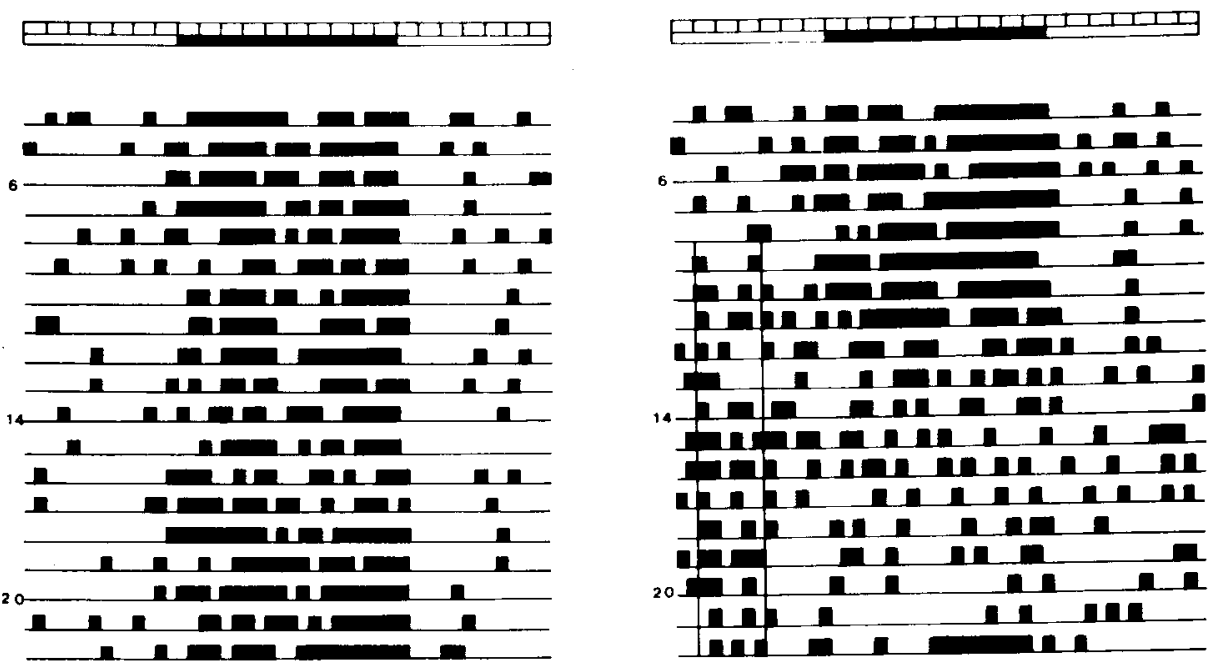

FIG. 3. - Main daily periods of activity during gestation in 3 rats according to food avaibility. Part a : (top left) group $\mathrm{C}$, fed at will : Part $b$ : (top right) group 14PF, fed from $14 \mathrm{hr}$; Part $c$ : (bottom right) group $9 P F$, fed from $9 \mathrm{~h}$. For other details, see figure 2.
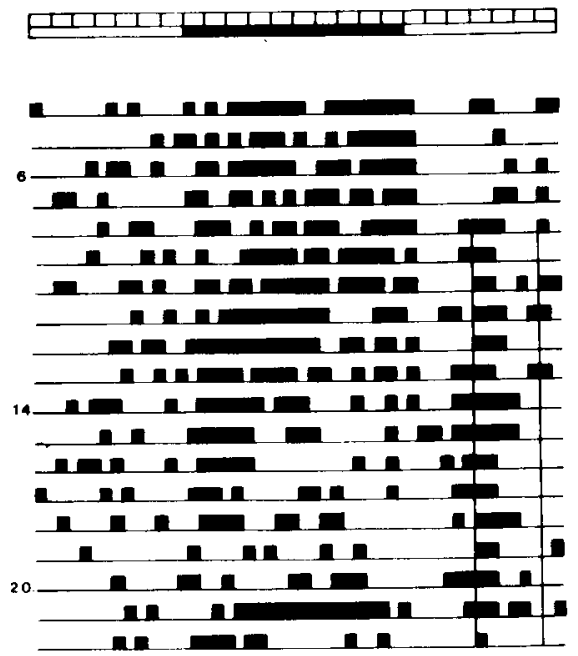

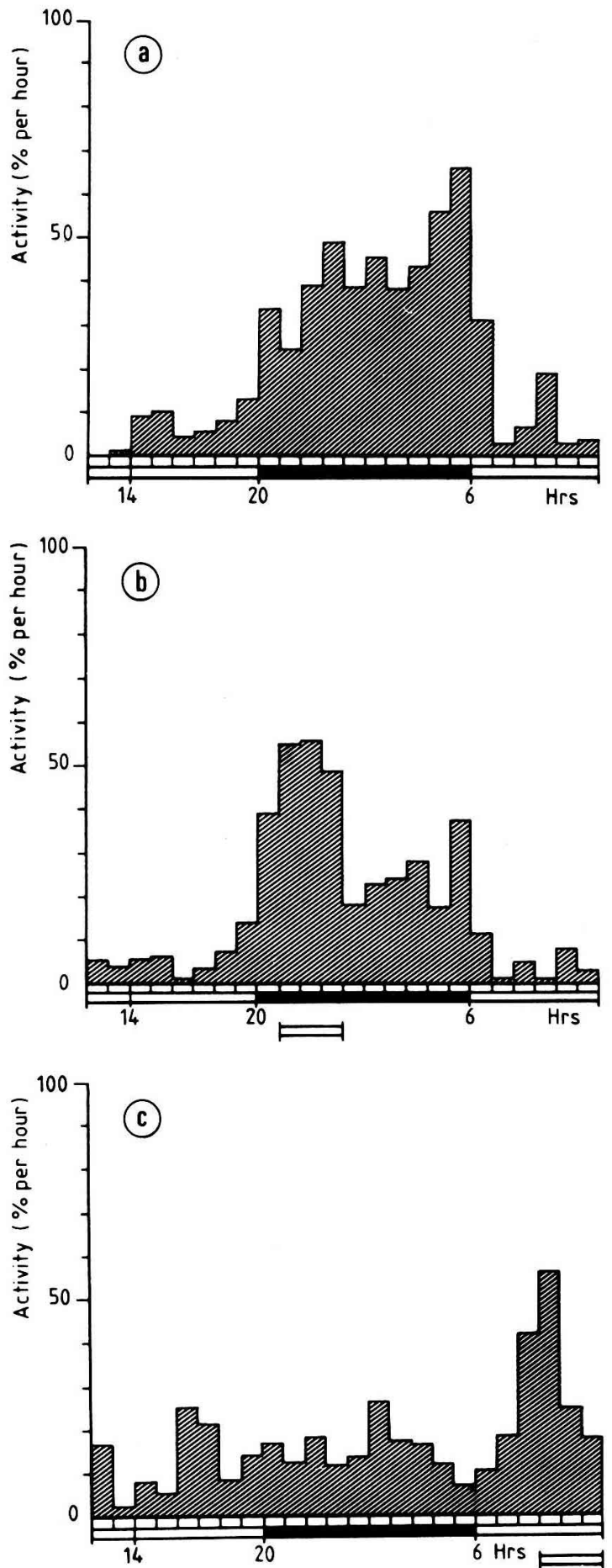

FIG. 4. - Mean distribution of physical activity (in \% per hour) over a 24-hour period at the end of gestation from noon on day 20. Part $a:($ top) group $C(n=6)$ feeding ad libitum; Part $b$ : (middle) group 21PF $(n=4)$ feeding between 21 and $24 \mathrm{hrs}$; Part $c$ : (bottom) group $9 \mathrm{PF}(\mathrm{n}=6)$ feeding between 9 and $12 \mathrm{hrs}$. The circadian scale, the LD cycle and time of food avaibility in rats fed 3 hrs daily (from day 8 of gestation) are indicated at the bottom of each panel. 
periods of activity. These results were confirmed when all activity times per hour and per group were taken into account at the three selected stages of pregnancy. They are illustrated in only three groups in figure 4 (group $C$ : part a; group 21PF : part b ; group 9PF : part c) over a 24-hour period, beginning from noon on day 20 , at the end of gestation. In all groups, there was a decrease in the total amount of daily activity from day $6 / 7$ to day $20 / 21$ of gestation, and this decrease was apparently more pronounced in rats fed periodically than in the controls (table 3). According to the values of the Spearman rank coefficients, the activity patterns of control rats or those fed during darkness (groups 2PF and 21PF) were more homogeneous (table 3 ). This was not the case of rats fed during the light phase (groups 9PF and 14PF) ; the daily activity pattern of these animals was disturbed the most (table 3), even if they were more active at food presentation than at all other times of the day (figs. $3 c, 3 b$ or fig. $4 c$ ).

\section{TABLE 3}

Mean activity time ( $\mathrm{min} / \mathrm{rat}$ ) and Spearman rank coefficients ( $\mathrm{r}$ ) computed per 24-hour period at three stages of pregnancy.

\begin{tabular}{llcccccc}
\hline & & $\mathrm{C}$ & $2 \mathrm{PF}$ & $9 \mathrm{PF}$ & $14 \mathrm{PF}$ & $21 \mathrm{PF}$ & $\begin{array}{c}\text { Total } \\
\text { (groups) }\end{array}$ \\
\hline Rats : $(\mathrm{n})$ & & 6 & 3 & 6 & 5 & 4 & \\
\hline Day 6/7 & Time & 448 & 429 & 446 & 443 & 368 & 431 \\
& $\mathrm{r}$ & $0.67^{* *}$ & $0.77^{* *}$ & $0.54^{* *}$ & $0.49^{*}$ & $0.49^{*}$ & $0.76^{* *}$ \\
\hline Day 14/15 & Time & 356 & 308 & 404 & 350 & 378 & 364 \\
& $\mathrm{r}$ & $0.59^{* *}$ & $0.61^{* *}$ & $0.35^{* *}$ & 0.13 & $0.64^{* *}$ & 0.32 \\
\hline Day 20/21 & Time & 337 & 232 & 251 & 235 & 253 & 267 \\
\hline Total (days) & $\mathrm{r}$ & $0.66^{* *}$ & 0.37 & 0.18 & 0.30 & $0.59^{* *}$ & 0.05 \\
\hline & Time & 380 & 323 & 367 & 342 & 333 & 353 \\
\hline
\end{tabular}

$r={ }^{*} \mathrm{p}<0.05 ;{ }^{*} \mathrm{p}<0.01$

Day $6 / 7$ before, day $14 / 15$ and $20 / 21$ after the beginning (day 8 ) of periodic food presentation in groups 2PF, 9PF, 14PF and $21 \mathrm{PF}$.

Group $\mathrm{C}$ : feeding ad libitum throughout gestation.

Intra-group and inter-group rank coefficients $r$ were also estimated.

\section{Discussion.}

The results of this experiment confirm that feeding rhythms are potent modulators of birth time in rats. These rhythms act by an interaction with the photoperiod, as observed previously in other conditions (Bosc and Nicolle, 1985). The two types of activity, i.e. delivery or end of labor and feeding or related behaviour, occurred at different times of the day, indicating that the endogenous clock of the pregnant rats was regulated in such a way that either labor had to precede

Reproduction, Nutrition, Développement, $n^{\circ}$ 3-1986. -3 
feeding or its associated activity, or follow it, depending on the environmental conditions. These results provide an insight into the endogenous organization in rats which leads to birth in this species.

The interaction between the photoperiod and the feeding rhythm is illustrated by the variation in the interval between the onset of expulsion and a given reference point, chosen in regard to an exogenous signal (here, last dawn or last feeding) (table 1). The feeding procedures had different effects according to the time of food presentation. For example, in the two groups of rats fed during the light phase (groups 9PF and 14PF), the first-half of birth was delayed and the other half advanced as compared to rats fed ad libitum (group $\mathrm{C}$, fig. $1 \mathrm{~b}$ ). The difference in the interval between feeding and birth raises a question concerning the putative variations in the duration of labor or in the time at which birth is initiated. It is not known if the mean duration of labor in rats is subject to circadian variation, as described in humans (Malek et al., 1962 ; Breart and Rumeau-Rouquette, 1979) ; however, it is unlikely. The still-birth rate, which increases with the duration of expulsion (Bosc and Nicolle, 1979), was low in all groups (table 2) and thus provides an indirect argument for this statement. In contrast, it is known in this species that the interval (about $25 \mathrm{~h}$ ) between the necessary decline in blood progesterone concentration and the onset of birth remains constant under photoperiodic conditions which have been studied (Bartholomeusz et al., 1976 ; Nicholas and Hartmann, 1981 ; Puri and Garfield, 1982 ; Sherwood et al., 1983). It is also worth noting that, in this species, the increase of EMG activity of the uterus starts 20 to $24 \mathrm{~h}$ before the first fetus is expulsed (Legrand and Maltier, 1981 ; Germain et al., 1985). This suggests that, in our conditions, the time of luteolysis and the beginning of labor may occur at different times of the day, depending on the phase relationships of the two exogenous entrainers.

The obligatory shift between delivery and feeding is illustrated by the following facts. The feeding procedure adopted in this experiment generated a main circadian period of activity at the time of food availability (figs. $2,3,4$ ) and resulted in definite and characteristic birth distributions (fig. 1). From the records of activity and from the birth distribution curves, it can be seen that births occurred during the least active period of the day and never during the feeding periods. The control rats fed at will and normally active during darkness (figs. $2,3,4$ ) delivered before or after the night between days 22 and 23 of gestation (fig. 1). Feeding the rats during the afternoon (group 14PF) or the morning (group 9PF), times at which they would have given birth if fed ad libitum, caused parturition to occur between these times (fig. 1b). At least, ad libitum rats preferentially ate their food at the beginning and end of the noctural period (Obled et al., 1975) ; feeding the rats at one of these times (group 21PF or 2PF) resulted in two periods of birth, as for the controls, but changed the birth rate of each period (fig. 1).

The opposition between birth and the main active periods of the day and/or feeding suggests that the time of birth in rats is regulated by at least two endogenous oscillators related to dawn and dusk. It has already been shown that the nocturnal period of locomotor activity (Pittendrigh and Daan, 1976), or wheel running activity (Edmonds and Adler, 1977), in rodents is controlled by such a mechanism. This is also true of the time of ovulation which is delayed by dusk 
light and advanced by dawn light (Sridaran and McCormack, 1979, 1980 ; McCormack and Sontag, 1980). The results observed in the groups fed at the beginning (21PF) or end (2PF) of the night support this interpretation of two oscillators; these two feeding regimes emphasize the effects of photoperiod (fig. 1a) and therefore the effects of the endogenous events normally related to lights off or to lights on. As for ovulation, lights off had an inhibitory effect on birth (Bosc, 1981) which was reinforced by the presentation of food at that time. By contrast, lights on had a stimulatory influence since the birth period began at dawn on day 23 of gestation in rats fed at will and put under different photoperiods (fig. 1) (Bosc, 1981). The 25-hour latency observed between luteolysis and birth (Bartholomeusz et al., 1976 ; Nicholas and Hartmann, 1981 ; Puri and Garfield, 1982 ; Sherwood et al., 1983) also supports such a mechanism. In this model applied to environmental conditions and birth time in rats, a third component must be included. Two definite periods of birth are often observed, depending on the photoperiod (Bosc, 1981) or the feeding regime (Bosc and Nicolle, 1985) (groups C, 2PF and $21 \mathrm{PF}$ in this present experiment). The first period began after midday or noon (colony time) on day 22 of gestation but not necessarily at dawn (fig. 1 ; groups $\mathrm{C}, 2 \mathrm{PF}$ and 21PF). In other words, the interval between the mean time of the two birth periods, when observed, was less than $24 \mathrm{~h}$ (here, 16-17 $\mathrm{h}$ for group $\mathrm{C}, 19$ $21 \mathrm{~h}$ for group 2PF and 21PF). This third component is probably influenced by factors limiting variations in the length of gestation. Birth cannot be initiated in a given strain before a certain time, and that time depends to some extent on litter size and/or fetal maturity (Reynolds, 1965 ; Bosc and Nicolle, 1980).

In this experiment, the total activity time decreased as gestation progressed. This was probably due to pregnancy itself but perhaps also to the fact that the rats were isolated at mating. The feeding procedure certainly exerted some effect since the decrease in activity time was more pronounced in rats fed three hours per day than in the controls (table 3 ). It is interesting also to note that the relative weight gain of the dams during gestation as well as the birth weight of the pups was lower in the groups submitted to periodic food presentation than in those fed ad libitum (table 2). The main reason was probably the reduction of dam food intake as observed in non-pregnant females under similar conditions (Krieger, 1974 ; Krieger et al., 1977 ; Morimoto et al., 1979). However, the weight gain of the dams in the three groups fed periodically (2PF, 9PF, 21PF), and which showed different birth distributions (fig. 1), was within the same range (table 2). This indicates that feeding rhythm rather than probable reduced food intake was the main cause for the shifts in the delivery pattern.

Reçu en octobre 1985.

Accepté en janvier 1986.

Acknowledgements. - We wish to thank Messrs. Cahier, Pellan and Vigneau for animal care and the Mrs. Ploux and Bézard for typing the paper. We are indebted to Mr. Simonnet (Laboratoire de Physiologie Sensorielle, I.N.R.A., Jouy-en-Josas) for the monitoring systems used to record physical activity. 
Résumé. Moment de la naissance et activité journalière chez la ratte. Influence des rythmes alimentaires.

L'étude des relations temporelles entre le moment de la naissance et l'activité quotidienne a été réalisée sur des rattes soumises selon le lot à différents rythmes alimentaires. Les animaux, placés sous $14 \mathrm{~h}$ de lumière et $10 \mathrm{~h}$ d'obscurité (lumière de 6 à $20 \mathrm{~h}$ ) ont été isolés à la saillie $\left(\mathrm{J}_{1}\right.$ de la gestation) et répartis à partir de $\mathrm{J}_{8}$ dans les 5 lots suivants : lot $\mathrm{C}$, nourriture " ad libitum ", lots 2PF-9PF-14PF et 21PF nourriture disponible $3 \mathrm{~h} /$ jour à partir de $2 \mathrm{~h}-9 \mathrm{~h}-14 \mathrm{~h}$ et $21 \mathrm{~h}$ respectivement. Dans les lots 9PF et 14PF, les naissances ont été groupées sur une seule période au cours de la nuit séparant $J_{22}$ et $J_{23}$. Dans les lots C-2PF et 21PF, les naissances ont été observées au cours de deux périodes; la 1ere au cours de l'après-midi de $J_{22}$ avant la nuit de $J_{22}$ à $J_{23}$, la $2^{e}$ après l'aube de $J_{23}$; pour ces trois lots $C$ $2 \mathrm{PF}$ et $21 \mathrm{PF}$, les taux de naissance ont été respectivement de 55,$3 ; 74,2$ et $27,6 \%$ à $\mathrm{J}_{22}$ et de $44,7-25,8$ et $72,4 \%$ à $J_{23}$. Les périodes de naissance ne sont jamais observées pendant les heures de disponibilité de l'aliment, elles correspondent aux moments où les animaux présentent l'activité quotidienne la plus faible d'après les enregistrements d'activité effectués en continu. Ainsi limiter la disponibilité des aliments aux périodes habituelles d'inactivité (lots 9PF et 14PF vs lot $\mathrm{C}$ ) entraîne les modifications les plus importantes des moments de naissance et des distributions de l'activité quotidienne.

Ces résultats confirment que le rythme alimentaire est un entraîneur efficace du moment de la mise-bas chez la ratte et qu'il agit en intéraction avec le régime lumineux. Ils montrent que selon les conditions de milieu la mise-bas doit suivre ou précéder le moment de l'activité quotidienne principale.

\section{Références}

BARTHOLOMEUSZ R. K., BRUCE N. W., MARTIN C. E., HARTMANN P. E., 1976. Serial measurement of arterial plasma progesterone levels throughout gestation and parturition in individual rats. Acta endocrinol., 82, 436-444.

BESCH E. L., 1970. Influence of photoperiod on food and water intake in rats. Aerospace Med., 41, 1145-1148.

BOSC M. J., 1981. Effects of photoperiod on the time of birth in the rat, 33-50. In Photoperiodism and reproduction, Int. Coll. Nouzilly (France). Ed. I.N.R.A. Versailles.

BOSC M. J., NICOLLE A., 1979. Effect of stress on the course of labor and parturition time in normal or adrenalectomized rats. Ann. Biol. anim. Bioch. Biophys., 19, 31-44.

BOSC M. J., NICOLLE A., 1980. Influence of photoperiod on the time of parturition in the rat. I. Effect of the length of daily illumination on normal or adrenalectomized animals. Reprod. Nutr. Dévelop., 20, 735-745.

BOSC M. J., NICOLLE A., 1985. Influence of photoperiod on the time of birth in the rat. IV Effects of an imposed feeding rhythm. Reprod. Nutr. Dévelop., 25, 39-48.

BREART G., RUMEAU-ROUQUETTE C., 1979. Rythmes spontanés et rythmes induits dans le déclenchement et le déroulement du travail et de l'accouchement. J. interdiscipl. Crcle Res., 10, 195-205.

EDMONDS S. C., ADLER N., 1977. The multiplicity of biological oscillators in the control of circadian running activity in the rat. Physiol. Behav., 18, 921-930.

GERMAIN G., LEGRAND C., MALTIER J. P., 1985. Implications of adrenoreceptors in the control of electrical activity of the preparturient uterus in the rat, 207-217. In S. BOTTARI, J. P. THOMAS, A. VOKAER, R. VOKAER, Uterine contractility. Masson Publ. USA Inc. N.Y.

KRIEGER D. T., 1974. Food and water restriction shifts corticosterone, temperature activity and brain amine periodicity. Endocrinology, 95, 1195-1201.

KRIEGER D. T., HAUSER M., KREY L. C., 1977. Suprachiasmatic nuclear lesions do not abolish food-shifted circadian adrenal and temperature rhythmicity. Science, 197, 398-399. 
LEGRAND C., MALTIER J. P., 1981. Activité électrique de l'utérus chez la rate préparturiente, 61-68. In Cl. BOURY-HEYLER, P. MAULĖON, Y. ROCHET, Utérus et fécondité. Ed. Masson, Paris.

LINCOLN D. W., PORTER D. G., 1976. Timing of the photoperiod and the hour of birth in rats. Nature, 260, 780-781.

McCORMAK Ch. E., SONTAG Ch. R., 1980. Entrainment by red light of running activity and ovulation rhythms of rats. Am. J. Physiol., 239, R 450-R 453.

MALEK J., GLEICH J., MALY V., 1962. Characteristics of the daily ihythm of menstruation and labor. Ann. N. Y. Acad. Sci., 98, 1042-1055.

MIYABO S., YANAGISAWA K. I., OOYA E., HISADA T., KISHIDA S., 1980. Ontogeny of circadian corticosterone rhythm in female rats. Effects of periodic maternal deprivation and food restriction. Endocrinology, 106, 636-642.

MORIMOTO Y., OISHI T., ARISUE K., YAMAMURA Y., 1979. Effect of food restriction and its withdrawal on the circadian adrenocortical rhythm in rats under constant dark or constant lighting conditions. Neuroendocrinology, 29, 77-83.

OBLED C., ARNAL M., FAUCONNEAU G., 1975. Synthèse protéique in vivo dans divers tissus du Rat en croissance en fonction du rythme alimentaire. Ann. Biol. anim. Bioch. Biophys. 15, 73-93.

OBLED C., ARNAL M., GRIZARD J., 1977. Influence du comportement alimentaire sur le rythme circadien de la corticostérone plasmatique chez le rat en croissance. C.R. Acad. Sci. Paris, Sér. D, 284, 195-198.

NICHOLAS K. R., HARTMANN P. E., 1981. Progressive changes in plasma progesterone, prolactin and corticosteroid levels during late pregnancy and the initiation of lactose synthesis in the rat. Aust. J. biol. Sci., 34, 445-454.

PITTENDRIGH C. S., DAAN S., 1976. A functional analysis of circadian pacemakers in nocturnal rodents. V. Pacemaker structure : a clock for all seasons. J. comp. Physiol, 106, 333-355.

PURI C. P., GARFIELD R. E., 1982. Changes in hormones levels and gap junctions in the rat uterus during pregnancy and parturition. Biol. Reprod, 27, 967-975.

REYNOLDS S. R. M., 1965. In The physiology of the uterus. Ed. Hafner Publ. Co. New York, $619 \mathrm{p}$.

SHERWOOD O. D., DOWNING S. J., GOLOS T. G., GORDON W. L., TARBELL M. K., 1983. Influence of light-dark cycle on antepartum serum relaxin and progesterone immunoactivity levels and on birth in the rat. Endocrinology, 113, 997-1003.

SIEGEL S., 1956. In " Non parametric statistics for the behavioral sciences ». Int. Student Ed. Mc. Graw Hill Book Inc, New York.

SRIDARAN R., McCORMAK Ch. E., 1979. Role of light in the timing of ovulation in rats: evidence that dawn light advances and dusk light delays ovulation. Biol. Reprod., 20, 705712.

SRIDARAN R., McCORMAK Ch. E., 1980. Parallel effects of light signals on the circadian rhythms of running activity and ovulation in rats. J. Endocr., 85, 111-120.

VESSEREAU A., 1960. In Recherche et expérimentation en agriculture, Tome 2, Méthodes statistiques en Biologie et en Agronomie. Ed. J. B. Baillères et Fils, Paris, p. 539. 